\title{
PENGGUNAAN MODEL DISCOVERY LEARNING UNTUK MENINGKATKAN AKTIVITAS DAN HASIL BELAJAR SISWA PADA TEMA 1 BENDA-BENDA DI LINGKUNGAN SEKITAR SUBTEMA 1 WUJUD BENDA DAN CIRINYA DI KELAS V SDN RANCASAWO 1
}

\author{
Abdul Mumin Saud ${ }^{1}$ \\ Elis Sri Rahayu² \\ 1abdulmuminsaud@unpas.ac.id \\ 2elis_1786@gmail.com \\ 1 Universitas Pasundan \\ ${ }^{2}$ SDN Rancasewo 1
}

\begin{abstract}
This study aims to improve the activity and student learning outcomes by using the model of Discovery Learning on the theme of objects in the environment around the subtema of the form of objects and characteristics. . This research was conducted in class V SDN Rancasawo 01 and the background of students who showed less activity in the learning process and the result of learning that still have not reached the minimum mastery criteria, this is because teachers often use lecture methods that tend to monoton and have not used the model of Discovery Learning. Assessment used in this research is pretest and post test technique to know student learning result, activity assessment and observation sheet to know teacher and student attitudes during learning process. The results showed an increase in the mean of the activity assessment and the results of the learning test. In the activity assessment the average value of cycle 1 is 58.57, while cycle 2 reaches $80 \%$ and cycle 3 reaches $90 \%$. The learning outcomes in cycle 1 average value that is equal to 54,61\%, in cycle 2 reach 80,38\% and result learn at cycle 3 reach 91,79\%. This shows that the use of discovery learning model can improve the activity and learning outcomes of students on the theme of objects in the surroundings around the subtheme of objects and the characteristics of class $V$ SDN Rancasawo 01. Thus, the use of the model of Discovery Learning can be used as one of the learning models to be applied to Thematic learning with other themes and subthemes.
\end{abstract}

Keywords: Discovery Learning, Activities, learning outcomes.

\begin{abstract}
ABSTRAK
Penelitian ini bertujuan untuk meningkatkan aktivitas dan hasil belajar siswa dengan menggunakan model Discovery Learning pada tema benda-benda di lingkungan sekitar subtema wujud benda dan cirinya. Penelitian ini dilaksanakan dikelas V SDN Rancasawo 01 dan dilatar belakangi keadaan siswa yang kurang menunjukkan aktivitas di dalam proses pembelajaran dan hasil belajar yang masih banyak belum mencapai kriteria ketuntasan minimal,
\end{abstract}


hal ini karena guru sering menggunakan metode ceramah yang cenderung monoton dan belum menggunakan model Discovery Learning. Penilaian yang digunakan pada penelitian ini adalah teknik tes pretest dan postest untuk mengetahui hasil belajar siswa, penilaian aktivitas dan lembar observasi untuk mengetahui kegaiatan guru dan siswa selama proses pembelajaran. Hasil penelitian menunjukkan adanya peningkatan rata-rata dari penilaian aktivitas dan hasil tes belajar. Pada penilaian aktivitas nilai rata-rata siklus 1 yaitu 58,57, sedangkan siklus 2 mencapai $80 \%$ dan siklus 3 mencapai $90 \%$. Hasil belajar pada siklus 1 nilai rata-rata yaitu sebesar $54,61 \%$, pada siklus 2 mencapai $80,38 \%$ dan hasil belajar pada siklus 3 mencapai $91,79 \%$. Hal ini menunjukkan bahwa penggunaan model discovery learning dapat meningkatkan aktivitas dan hasil belajar siswa pada tema benda-benda di lingkunga sekitar subtema wujud benda dan cirinya kelas V SDN Rancasawo 01 . Dengan demikian, penggunaan model Discovery Learning dapat dijadikan salah satu model pembelajaran untuk diterapkan pada pembelajaran tematik dengan tema dan subtema yang lainnya.

Kata kunci: Discovery Learning, Aktivitas, Hasil belajar.

\section{A. Pendahuluan}

Sistem pendidikan di Indonesia ternyata telah mengalami banyak perubahan. Perubahan-perubahan itu terjadi karena telah dilakukan berbagai usaha pembaharuan dalam pendidikan. Akibat pengaruh itu pendidikan semakin mengalami kemajuan.

Pendidikan mempunyai peranan penting dalam kemajuan bangsa dan Negara. Berhasil tidaknya pendidikan yang dilaksanakan, akan menentukan maju mundurnya suatu bangsa. Oleh sebab itu, salah satu tujuan bangsa Indonesia yang tertuang dalam pembukaan UUD 1945 adalah mencerdaskan kehidupan bangsa. Dalam rangka mewujudkan hal tersebut, pemerintah melalui lembagalembaga pendidikan dari tingkat dasar, yang meliputi Sekolah Dasar atau Madrasah Ibtidaiyah, Sekolah Menegah Pertama atau Madrasah Tsanawiah, Sekolah Menengah Atas atau Madrasah Aliyah, Sekolah Kejuruan sampai pada tingkat Universitas atau Perguruan Tinggi berusaha mencetak generasi-generasi yang cerdas serta dapat meningkatkan harkat dan martabat bangsa Indonesia.

Dalam Undang-Undang Republik Indonesia No. 20 Tahun 2003 Tentang Sistem Pendidikan 
Nasional (UU Sisdiknas) Pasal 1, pengertian pendidikan adalah sebagai berikut.

"Pendidikan adalah usaha sadar dan terencana untuk mewujudkan suasana belajar dan proses pembelajaran agar peserta didik secara aktif mengembangkan potensi dirinya untuk memiliki kekuatan spiritual keagamaan, pengendalian diri, kepribadian, kecerdasan, akhlak mulia, serta keterampilan yang diperlukan dirinya, masyarakat, bangsa, dan Negara".

Kemudian dalam UndangUndang Republik Indonesia Nomor 14 Tahun 2005 Tentang Guru dan Dosen Bab 1 Pasal 1 menyatakan, "Guru adalah pendidik profesional dengan tugas utama mendidik, mengajar, membimbing, mengarahkan, melatih, menilai, dan mengevaluasi peserta didik pada pendidikan anak usia dini jalur pendidikan formal, pendidikan dasar, dan pendidikan menengah".

Peraturan Pemerintah Nomor 32 Tahun 2013 tentang Standar Nasional Pendidikan bahwa, "Kurikulum adalah seperangkat rencana dan pengaturan mengenai tujuan, isi dan bahan pelajaran serta cara yang digunakan sebagai pedoman penyelenggaraan kegiatan pembelajaran untuk mencapai tujuan pendidikan tertentu".

Peraturan Menteri Pendidikan dan Kebudayaan Republik Indonesia No. 24 Tahun 2016 tentang Kompetensi Inti dan Kompetensi Dasar Pelajaran pada Kurikulum 2013 menurut peraturan ini bahwa. "Kompetensi inti pada kurikulum 2013 merupakan tingkat kemampuan untuk mencapai standar kompetensi lulusan yang harus dimiliki seorang peserta didik pada setiap tingkat kelas. Sementara yang dimaksud dengan kompetensi dasar adalah kemampuan dan materi pembelajaran minimal yang harus dicapai peserta didik untuk suatu mata pelajaran pada masingmasing satuan pendidikan yang mengacu pada kompetensi inti".

Sejalan dengan kemajuan tersebut, maka dewasa ini pendidikan di sekolah-sekolah telah menunjukkan perkembangan yang sangat pesat. Perkembangan itu terjadi 
karena terdorong adanya pembaharuan tersebut, sehingga di dalam pengajaran pun guru selalu ingin menemukan metode dan peralatan baru yang dapat memberikan semangat belajar bagi semua siswa. Bahkan secara keseluruhan dapat dikatakan bahwa pembaharuan dalam sistem pendidikan yang mencakup seluruh komponen yang ada.

Pada hakekatnya kegiatan belajar mengajar adalah suatu proses interaksi atau hubungan timbal balik antara guru dan siswa dalam satuan pembelajaran. Guru sebagai salah satu komponen dalam proses belajar mengajar merupakan pemegang peran yang sangat penting. Guru bukan hanya sekedar penyampai materi saja, tetapi lebih dari itu guru dapat dikatakan sebagai sentral pembelajaran.

Berhasilnya pembelajaran ditentukan oleh banyak faktor di antaranya adalah faktor guru dalam melaksanakan proses belajar mengajar, karena guru secara langsung dapat mempengaruhi, membina dan meningkatkan kecerdasan serta keterampilan siswa. Untuk mengatasi permasalahan di atas dan guna mencapai tujuan pendidikan secara maksimal, peran guru sangat penting dan diharapkan guru memiliki cara/model mengajar yang baik dan mampu memilih model pembelajaran yang tepat dan sesuai dengan pembelajaran yang akan disampaikan.

Sebagai pengatur sekaligus pelaku dalam proses belajar mengajar, gurulah yang mengarahkan bagaimana proses belajar mengajar itu dilaksanakan. Karena itu guru harus dapat membuat suatu pembelajaran menjadi lebih menarik, sehingga bahan pembelajaran yang disampaikan akan membuat siswa merasa senang dan merasa perlu untuk mempelajari pembelajaran tersebut. Dengan begitu siswa akan mencapai keberhasilan dalam belajarnya.

Dewasa ini, telah terjadi pergeseran pola mengajar yaitu dari guru yang mendominasi kelas 
menjadi guru sebagai fasilitator dalam proses pembelajaran, dalam rangka meningkatkan hasil belajar, guru harus menciptakan kondisi belajar yang aktif. Tetapi ada suatu penghambat keberhasilan belajar siswa yang merupakan masalahmasalah yang sering terjadi dalam pembelajaran dikelas. Dari hasil observasi yang telah saya laksanakan di SDN Rancasawo 1, masalah-masalah yang mengakibatkan menurunnya hasil belajar siswa antara lain, metode pembelajaran yang konvensional, berpusat pada guru, tidak adanya interaksi yang memunculkan keaktifan siswa.. Dalam kenyataannya, guru dikelas V SDN Rancasawo 1 ini belum bisa mengolah pembelajaran menarik, guru masih melakukan kegiatan pembelajaran yang bersifat tradisional yaitu dengan menggunakan metode ceramah dan mengajarnya hanya satu arah saja, sehingga siswa pasif dan hanya menjadi pendengar saja tanpa kita tidak ketahui apakah siswa tersebut mengerti atau tidak dengan materi yang disampaikan. Guru dalam mengajar hanya mengenal target kurikulum tanpa memperhatikan apakah konsep yang diajarkan sudah dipahami oleh siswa. Pada kelas V SDN Rancasawo 1 ini jumlah siswa yang tidak berhasil pada belajar berjumlah 15 orang dari 36 siswa yang nilainya dibawah KKM. Standar KKM adalah 75. Seorang guru mempunyai skenario pembelajaran yang baik dan menarik maka hasil belajar siswa dalam hal ini akan meningkat. Guru harus menyiapkan pembelajaran yang menarik minat, memiliki metode belajar, strategi, pendekatan dan alat peraga, sehingga hasil belajar siswa menjadi meningkat.

Untuk itu diperlukan suatu upaya dalam rangka meningkatkan hasil belajar salah satunya adalah dengan memilih model atau cara dalam menyampaikan pembelajaran agar diperoleh peningkatan hasil belajar siswa. Misalnya dengan membimbing belajar siswa dengan menggunakan suatu cara untuk bersama-sama terlibat aktif dalam proses pembelajaran dan mampu 
membantu siswa berkembang sesuai dengan taraf intelektualnya akan lebih menguatkan pemahaman siswa terhadap pembelajaran yang dilaksanakan.

Berdasarkan pengalaman di lapangan, kurangnya hasil belajar rata-rata dihadapi oleh sejumlah siswa yang tidak memiliki dorongan belajar. Sehingga nilai rata-rata dalam suatu pembelajaran cukup rendah. Hal ini disebabkan karena guru dalam proses belajar mengajar hanya menggunakan metode ceramah, tanpa menggunakan alat peraga, dan materi pelajaran tidak disampaikan secara kronologis. Untuk itu dibutuhkan suatu kegiatan yang dilakukan oleh guru dengan upaya meningkatkan hasil belajar siswa, misalnya dengan membimbing siswa untuk terlibat langsung dalam kegiatan yang melibatkan siswa serta guru yang berperan sebagai pembimbing.

Menghadapi kenyataan tersebut, peneliti tertarik untuk melakukan tindakan-tindakan perbaikan terhadap hasil belajar siswa dalam pembelaran. Perbaikan yang dilakukan mengenai penerapan model Discovery Learning untuk mengungkapan apakah dengan model penemuan dapat meningkatkan hasil bejalar siswa pada tema tersebut. Model discovery learning adalah memahami konsep, arti, dan hubungan, melalui proses intuitif untuk akhirnya sampai kepada suatu kesimpulan Discovery terjadi bila individu terlibat, terutama dalam penggunaan proses mentalnya untuk menemukan beberapa konsep dan prinsip. Model pembelajaran ini mengondisikan siswa untuk terbiasa menemukan, mencari, mendiskusikan sesuatu yang berkaitan dengan pengajaran. Dalam model ini siswa lebih aktif dalam memecahkan untuk menemukan sedangkan guru berperan sebagai pembimbing atau memberi petunjuk cara memecahkan masalah itu. Harapannya dengan diterapkannya model ini bisa terjadinya pembelajaran yang aktif, menarik, 
kreatif untuk siswa dan dapat menumbuhkan pemahaman bagi siswa sehingga dalam hasil belajarnya akan meningkat.

Berdasarkan latar belakang, penulis mengadakan penelitian yang berjudul "Penggunaan Model Discovery Learning Untuk Meningkatkan Hasil Belajar Siswa Pada Tema 1 Benda-benda di Lingkungan Sekitar Subtema 1 Wujud Benda dan Cirinya di Kelas V SDN Rancasawo 1"

\section{B. Landasan Teori}

\section{Model Discovery Learning}

\section{a. Pengertian Model Discovery}

\section{Learning}

Apabila ditinjau dari katanya, Discover berarti menemukan, sedangkan discovery adalah penemuan. Dalam kaitannya dengan pendidikan, Oemar Hamalik (dalam Takdir, 2012, hlm.29) menyatakan bahwa "discovery adalah proses pembelajaran yang menitikberatkan pada mental intelektual para anak didik dalam memecahkan berbagai persoalan, sehingga menemukan suatu konsep atau generalisasi yang dapat diterapkan dilapangan". Dengan kata lain, kemampuan mental intelektual.

Menurut Kosasih (2014, hlm. 83) mengemukakan bahwa "model discovery learning merupakan nama lain dari pembelajaran penemuan. Sesuai dengan namanya, model ini mengarahkan siswa untuk dapat menemukan sesuatu melalui proses pembelajaran yang dilakoninya".

Adapun menurut Mulyasa (2016, hlm. 144) mengemukakan "discovery learning merupakan model pembelajaran untuk menemukan sesuatu yang bermmakna dalam pembelajaran yang dilakukan dengan prosedur atau langkah-langkah". Menurut Asri Budiningsih (dalam Rina Agustina, 2016, hlm. 15) model discovery learning adalah memahami konsep, arti, hubungan melalui proses intuitif untuk akhirnya sampai kepada suatu kesimpulan.

Sedangkan menurut Bruner (dalam Takdir Illahi, 2012, hlm.41), mengemukakan implikasi Discovery Learning sebagai berikut: Pertama, melalui 
pembelajaran Discovery Learning, potensi intelektual siswa akan semakin meningkat, sehingga menimbulkan harapan baru untuk menuju kesuksesan. Kedua, Dengan menekankan Discovery Learning, anak didik akan belajar mengorganisasikan

dan menghadapi problem dengan metode hit and miss. Ketiga, Discovery Learning yang diperkenalkan Bruner mengarah pada self reward. Dengan kata lain, anak didik akan mencapai kepuasan karena telah menemukan pemecahan sendiri, dan dengan pengalaman memecahkan masalah itulah, ia bisa menigkatkan skill dan teknik dalam pekerjaannya melalui problem-problem rill di lingkungan ia tinggal.

Berdasarkan pendapat para ahli di atas, dapat disimpulkan bahwa model Discovery Learning adalah model pembelajaran yang dimana siswa berpikir sendiri sehingga dapat "menemukan" prinsip umum yang diinginkan dengan bimbingan dan petunjuk dari guru berupa pertanyaanpertanyaan yang mengarahkan.

\section{b. Tujuan Menggunakan Model Discovery Learning}

Menurut Mohammad Takdir llahi (2012, hlm, mengemukakan tujuan belajar discovery learning sebagai berikut:

1) Untuk mengembangkan kreativitas;

2) Untuk mendapatkan pengalaman langsung dalam belajar;

3) Untuk mengembangkan kemampuan berpikir rasional dan kritis;

4) Untuk meningkatkan keaktifan anak didik dalam proses pembelajaran;

5) Untuk belajar memecahkan masalah, dan;

6) Untuk mendapatkan inovasi dalam proses pembelajaran.

Adapun Mohammad Takdir Illahi (2012, hlm, 37) "pembelajaran Discovery bertujuan untuk mendapatkan pengalaman belajar yang sesuai dengan kondisi fisik dan mental anak didik dalam menerima materi pembelajaran yang diberikan". Selain itu Bell ( dalam Hosnan, 2014, hlm. 284) mengemukakan beberapa tujuan spesifik dari pembelajaran dengan penemuan, yakni sebagai berikut: 
1) Dalam penemuan siswa memiliki kesempatan untuk terlibat secara aktif dalam pembelajaran. Kenyataan menunjukan bahwa partisipasi siswa dalam pembelajaranmeningkat ketika penemuan digunakan

2) Melalui pembelajaran dengan penemuan, siswa belajar menemukan pola dalam situasi konkrit maupun abstrak,juga siswa banyak meramalkan informasi tambahan yang diberikan

3) Siswa juga merumuskan strategi tanya jawab yang tidak rancu dan menggunakan tanya jawab untuk memperoleh informasi yang bermanfaat

4) Pembelajaran dengan penemuan membantu siswa membentuk cara kerja bersama yang efektif, saling membagi informasi, serta mendengar dan menggunakan ide-ide orang lain

5) Terdapat beberapa fakta yang menunjukan keterampilan-keterampilan, konsep-konsep dan prinsipprinsip yang dipelajari melalui penemuan lenih bermakna

6) Keterampilan yang dipelajari dalam situasi belajar penemuan dalam beberapa kasus, lebih mudah ditranfer untuk aktivitas baru dan diaplikasikan dalam situasi belajar yang baru.

Berdasarkan beberapa pendapat diatas, maka dapat disimpulkan bahwa tujuan model Discovery Learning adalah siswa mampu mengolah dan menggali informasi sendiri melalui pengalaman langsung dengan belajar memecahkan masalah sehingga mampu menggunakan proses mentalnya untuk menemukan suatu konsep atau teori yang sedang dipelajari.

\section{c. Karakteristik Model Discovery Learning}

Model pembelajaran

Discovery Learning memiliki karakteristik yang menjadi ciri khas daripada model pembelajaran yang lainnya. Karakteristik Discovery Learning menurut Kuhlthau, Maniotes dan Caspari dalam Yunus Abidin (2013, hlm. 152) sebagai berikut:

1) Mempresentasikan konsep belajar seumur hidup.

2) Terintegrasi dalam seluruh mata pelajaran, menggunakan berbagai sumber belajar dan menekankan pencapaian proses belajar.

3) Mentransfer konsep-konsep informasi.

4) Melibatkan siswa secara aktif dalam seluruh tahapan pembelajaran dari tahap awal hingga tahap akhir.

5) Pembelajaran senantiasa dihubungkan dengan konteks kehidupan siswa.

6) Pembelajaran dilangsungkan dalam komunitas belajar yang kolaboratif dan kooperatif.

7) Guru dan siswa sama-sama terlibat aktif selama proses pembelajaran. 


\section{Dahar (dalam Syafriani,} 2017, hlm. 13) mengemukakan peranan guru dalam pembelajaran dengan penemuan, yakni sebagai berikut

1) Merencanakan pembelajaran sedemikian rupa sehingga pembelajaran itu berpusat pada masalah-masalah yang tepat untuk diselidiki para siswa

2) Menyediakan materi pelajaran yang diperlukan sebagai dasar bagi para siswa untuk memecahkan masalah. Sudah seharusnya materi pembelajaran itu dapat mengarah pada pemecahan masalah yang aktif dan belajar penemuan misalnya dengan menggunakan faktafakta yang berlainan.

3) Guru juga harus memperhatikan cara penyajian yang enactive, iconic, dan simbolik.

4) Bila siswa memecahkan masalah di laboraturium atau secara teoritis, guru hendaknya berperan sebagai pembimbing atau tutor.

5) Menilai hasil belajar merupakan suatu masalah dalam belajar penemuan. Secara garis besar tujuan belajar penemuan adalah mempelajari generalisasigeneralisasi dengan menemukan generalisasigeneralisasi.

d. Langkah-Langkah

Pembelajaran

Model

Learning

Discovery

Menurut Mohammad Takdir

Illahi (2012, hlm. 82) Langkah- langkah model discovery learning

meliputi:

(1) Adanya masalah yang akan dipecahkan

(2) Sesuai dengan tingkat kemampuan kognitif anak didik

(3) Konsep atau prinsip yang ditemukan harus ditulis secara jelas

(4) Harus tersedia alat atau bahan yang diperlukan

(5) Suasana kelas harus diatur sedemikian rupa;

(6) Guru memberikan kesempatan anak didik untuk mengumpulkan data;

(7) Harus dapat memberikan jawaban secara tepat sesuai dengan data yang diperlukan anak didik

Selain itu, Abu Ahmadi dan Joko Tri Prasetya (dalam Takdir, 2012, hlm. 87) mengemukakan secara garis besar bahwa prosedur pembelajaran berdasarkan penemuan ( Discovery Based Learning) adalah sebagai berikut:

1) Simulation, yaitu guru mengajukan persoalan atau meminta anak didik untuk membaca atau mendengarkan uraian yang memuat persoalan.

2) Problem statemen, yaitu anak didik diberi kesempatan mengidentifikasi berbagai permasalahan.

3) Data collection. Untuk menjawab pertanyaan atau membuktikan hopotesis, anak didik diberi kesempatan untuk mengumpulkan data dan informasi yang dibutuhkan, 
seperti membaca literatur, mengamati objek, melakukan wawancara dengan narasumber, melakukan uji coba sendiri, dan lain sebagainya.

4) Data processing. Semua informasi hasil bacaan wawancara observasi diklasifikasi dan ditabulasi, bahkan bila perlu dihitung dengan cara tertentu, serta ditafsirkan pada tingkat kepercayaan tertentu.

5) Verification. Berdasarkan hasil pengolahan dan tafsiran atau informasi yang ada, pertanyaan hipotesis yang dirumuskan sebaiknya dicek terlebih dahulu, apakah bisa terjawab dan terbukti drngan baik sehingga hasilnya akan memuaskan.

6) Generalization. Dalam tahap ini anak didik belajar menarik kesimpulan dan generalisasi tertentu.

\section{Adapun menurut Kosasih}

(2014, hlm. 85) pembelajaran discovery memiliki langkah-langkah yang sistematis, yakni sebagai berikut:

1) Perencanaan

(a) Menentukan KD dan mengembangkannya ke dalam tujuan pembelajaran beserta indikator-indikatornya

(b) Melakukan identifikasi masalah yang layak ditemukan jawabannya oleh para siswa. Dalam hal ini harus diperhatikan tingkat kesulitan permasalahannya sehingga siswa bisa menyelesaikannya dengan baik (c) Menyusun kegiatan dilakukan siswa terkait kegiatan penemuan itu beserta perangkat-perangkat pembelajaran yang dibutuhkan

2) Pelaksanaan

a) Merumuskan masalah. Guru menyampaikan masalah untuk menggugah dan menimbulkan kepenasaran-kepenasaran tentang fenomena tertentu. Masalah itu mendorong siswa untuk mau melakukan suatu rangkaian pengamatan mendalam

b) Membuat jawaban sementara (hipotesis). Siswa diajak melakukan identifikasi masalah yang kemudian diharapkan bisa bermuara pada perumusan jawaban sementara. Misalnya, ketika para siswa dihadapkan pada pertanyaan

c) Mengumpulkan data. Hipotesis merupakan jawaban sementara. Oleh karena itu perlu ada pembuktian untuk merumuskan benar tidaknya. Caranya adalah dengan pengumpulan data.

d) Perumusan kesimpulan. Setelah data terkumpul dan dianalisis, kemudian dikoreksi dengan rumusan masalah yang dirumuskan sebelumnya. Datadata tersebut digunakan untuk menjawab permasalahn tersebut. Kesimpulan itulah yang dimaksud dengan penemuan di dalam rangkaian kegiatan yang dilakukan siswa.

e) Mengkomunkasikan. Temuantemuan berharga siswa jangan dibiarkan terhenti dalam bentuk catatan-catatan berserakan. 
Hasil kegiatan mereka perlu ditindaklanjuti dengan kegiatan mengkomunikasikan. Temuantemuan mereka perlu dihargai, yakni dengan berupa kegiatan seminar.

\section{Metode Penelitian}

Metode penelitian digunakan dalam penelitian adalah penelitian tindakan kelas (PTK) atau ClassRoom Action Research. Penelitian tindakan kelas ditujukan untuk mencari solusi terhadap masalah-masalah yang terjadi di dalam kelas khususnya di dalam pembelajaran.

Dengan melaksanakan tahap-tahap PTK, guru dapat menemukan solusi dari masalah yang timbul dikelasnya sendiri. PTK mnjadi begitu penting karena membantu guru dalam hal memahami lebih baik tentang pembelajarannya,

mengembangkan keterampilan dan pengetahuannya, sekaligus dapat melakukan tindakan untuk meningkatkan belajar siswanya.

Menurut Ebbut (dalam Kunandar, 2012, hlm. 41) mengatakan PTK adalah kajian sistematik dari upaya perbaikan pelaksanaan praktik pendidikan oleh sekelompok guru dengan melakukan tindakan-tindakan dalam pemelajran, berdasarkan refleksi mereka mengenai hasil dari tindakan-tindakan tersebut.

Kemis dan Taggart (dalam Wibawa, 2014, hlm.02) mengemukakan bahwa penelitian tindakan adalah suatu bentuk penelitian reflektif diri kolektif yang dilakukan oleh pesertapesertanya dalam situasi sosial untuk meningkatkan penalaran dan keadilan praktik pendidikan dan praktik sosial mereka, serta pemahaman mereka terhadap praktik-praktik itu dan terhadap situasi tempat dilakukan praktikpraktik tersebut

Wardani (2014, hlm.03) mengemukakan bahwa penelitian tindakan kelas merupakan satu penelitian pula, yang dengan sendirinya mempunyai berbagai aturan dan langkah yang harus diikuti. Penelitian tindakan kelas merupakan terjemahan dari Classroom Action Research, yaitu satu Action Research yang dilakukan di kelas.

Sugiyono (2017, hlm. 6) menyatakan, Metode penelitian adalah cara-cara ilmiah untuk 
mendapatkan data yang valid, dengan tujuan dapat ditemukan, dikembangkan dan dibuktikan, suatu pengetahuan tertentu sehingga pada gilirannya dapat digunakan untuk memahami, memecahkan, dan mengantisipasi masalah.

Wardani (2014, hlm.04) mengemukakan bahwa ide pokok dari penelitian tindakan kelas adalah sebagai berikut:

1. Penelitian tindakan adalah satu bentuk inkuiri atau penyelidikan yang dilakukan melalui refleksi diri.

2. Penelitian tindakan dilakukan oleh peserta yang terlibat dalam situasi yang diteliti, seperti guru, siswa, atau kepala sekolah.

3. Penelitian tindakan dilakukan dalam situasi sosial, termasuk situasi pendidikan.

4. Tujuan penelitian tindakan adalah memperbaiki dasar pemikiran dan kepantasan dari praktik-praktik, pemahaman terhadap praktik tersebut, serta situasi atau lembaga tempat praktik tersebut dilaksanakan.

Dapat disimpulkan dari uraian pendapat para ahli tentang pengertian PTK diatas, bahwa Penelitian Tindakan Kelas merupakan suatu langkah yang dilakukan oleh peneliti atau oleh guru dalam mengatasi masalah dikelas khususnya dalam pembelajaran

Peneliti menggunakan metode ini dengan alasan karena metode penelitian ini sangat tepat jika digunakan untuk meneyelesaikan masalah yang timbul di dalam kelas, karena (PTK) sangat relevan dengan kebutuhan mengatasi maslaah dikelas. Langkah-langkah PTK secara garis besar adalah perencanaan, pelaksanaan, pengamatan dan refleksi.

\section{Pembahasan Hasil Penelitian}

Dalam pembahasan ini yang akan peneliti bahas meliputi tahap perencanaan, tahap pelaksanaan, aktivitas dan hasil belajar siswa yang di tingkatkan. Berikut ulasannya :

\section{Perencanaan Pembelajaran}

Pada siklus 1 peneliti masih kurang memaksimalkan pembelajaran dikarenakan gugup karena baru mengajar di kelas tersebut, namun meskipun begitu peneliti pernah melakukan pembelajaran sewaktu PPL 2 yang membuat tidak terlalu awam tentang perencanaan maupun pelaksanaan nya. 
Hal yang di lakukan peneliti adalah mempersiapkan RPP, menyusun alat pengumpulan data dan instrument pengumpulan, istrumen pengumpulan data yang digunakan adalah lembar observasi yang terdiri dari penilaian Rencana Pelaksanaan

Pembelajaran, penilaian

Pelaksanaan

Pembelajaran dan lembar observasi aktivitas guru dan siswa.

Hasil yang didapat oleh peneliti, didukung oleh beberapa pengertian menurut para ahli diantaranya adalah Rencana Pelaksanaan Pembelajaran (RPP) menurut Gintings dalam Azi (2012, hlm. 126) mengatakan bahwa RPP atau rencana pelaksanaan pembelajaran dapat disebut sebagai skenario pembelajaran. Dengan demikian RPP merupakan pegangan bagi guru untuk menyiapkan menyelenggarakan dan mengevaluasi hasil kegiatan belajar dan pembelajaran.

Menurut Majid dalam Azi (2012, hlm. 126) rencana pelaksanaan pembelajaran adalah rencana yang menggambarkan prosedur dan pengorganisasian pembelajaran untuk mencapai suatu kompetensi dasar yang ditetapkan dalam standard isi dan telah dijabarkan dalam silabus. Rekapitulasi rencana pelaksanaan pembelajaran siklus I, siklus II dan siklus III dapat dilihat pada diagram di bawah ini :

Diagram 4.15

Rekapitulasi Rencana

Pelaksanaan Pembelajaran

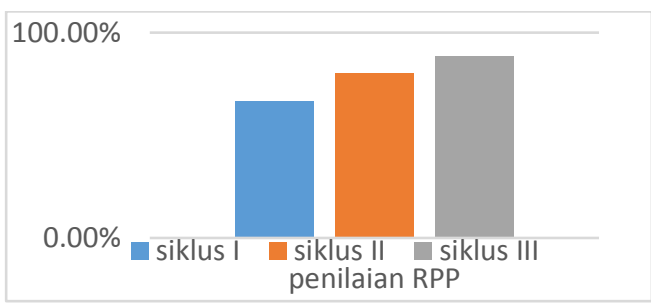

Berdasarkan

hasil penelitian perencanaan pembelajaran, dapat diketahui bahwa penelitian rencana pelaksanaan pembelajaran pada siklus I diperoleh nilai persentase $66,66 \%$ dengan kategori baik, siklus II diperoleh nilai persentase $83,33 \%$ dengan kategori baik dan pada siklus III diperoleh nilai persentase $91,78 \%$ dengan kategori sangat baik.

Sebelum melaksanakan proses kegiatan pembelajaran peneliti menyusun Rencana pelaksanaan pembelajaran dengan 
menggunakan kegiatan inti discovery learning

\section{Pelaksanaan Pembelajaran}

Pada saat melakukan pelaksanaan pembelajaran siklus I peneliti masih mengalami gugup karena menghadapi peserta didik yang baru, namun dengan seiring berjalannya waktu peneliti yang berperan sebagai guru lebih mendekati peserta didik agar tidak mengalami gugup lagi , pendidik lebih mendekat pada peserta didik agar terjalin rasa dalam melakukan pembelajaran yang menurut pendidik akan lebih berjalan lancer jika peserta didik dan pendidiik saling mengenal dan menumbuhkan rasa bahwa pendidik dan peserta didik ini teman jadi peserta didik tidak merasa malu dan tidak merasa takut kepada kita sebagai pendidik barunya . saat pelaksanaan berlangsung pendidik menerapkan langkah demi langkah pembelajaran discovery. Adapun beberapa pengertian menurut para ahli tentang model discovery learning dan pelaksanaan pembelajaran yang mendukung hasil yang di peroleh sehingga menjadi acuan dalam penelitian dibawah ini :

Discovery menurut Oemar Hamalik (dalam Takdir Ilahi, HIm. 29 ) mendefinisikan sebagai proses pembelajaran yang menitik beratkan pada mental intelektual para anak didik dalam memecahkan berbagai persoalan yang dihadapi, sehingga menemukan suatu konsep atau generalilasi yang dapat diterapkan dilapangan .

Pelaksanaan pembelajaran pada dasarnya merupakan sebuah proses yang diatur secara sistematis untuk mencapai suatu tujuan pembelajaran yang diinginkan hal ini sesuai dengan pendapat Sudjana dala Azi (2012, hIm. 115 ) mengatakan bahwa " pembelajaran adalah proses yang diselenggarakan oleh guru untuk membelajrakan siswa dalam belajar memperoleh dan memproses pengetahuan, keterampilan dan sikap".

Dengan seperti itu dapat di lihat pada saat pelaksanaan pembelajaran setiap harinya mengalami peningkatan apalagi pada tahap pelaksanaan pada 
siklus III dapat dilihat dengan jelas mengalami peningkatan yang dapat dilihat memalui diagram di bawah ini :

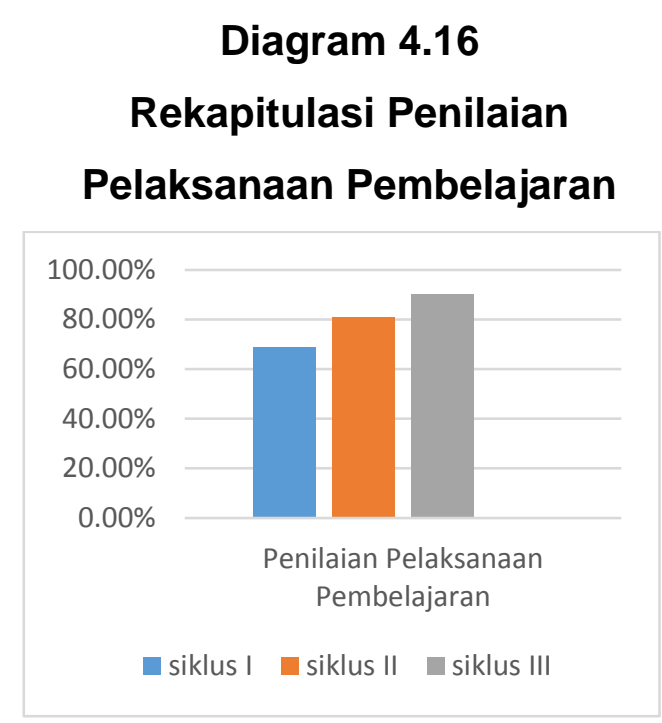

Berdasarkan diagram di atas dapat dilihat dengan jelas bahwa pelaksanaan pembelajaran setiap siklus nya mengalami peningkatan, di siklus I 68,66\%, siklus II yaitu $80,66 \%$ dan pada siklus III di peroleh $90 \%$

\section{Rekapitualasi Aktivitas Guru dan siswa}

Aktivitas belajar siswa dalam kegiatan pembelajaran sangat berperan untuk menghasilkan kegiatan pembelajaran yang aktif karena siswa mampu melakukan penemuan. Dalam penelitian ini peneliti berusaha menjawab rumusan masalah dan merealisasikan hipotesis yang telah diajukan dengan cara meningkatkan aktivitas dalam kegiatan pembelajaran subtema wujud benda dan cirinya dengan menggunakan model discovery learning. Dan secara keseluruhan dalam penelitian ini mampu meningkatkan aktivitas belajar siswa. Ini dapat dilihat dari presentase hasil penilaian aktivitas belajar siswa yang selalu meningkat.

Rusman (2012, hlm. 323) menyatakan "pembelajaran akan lebih bermakna jika siswa diberikan kesempatan untuk berpartisipasi dalam berbagai aktivitas belajar, sehingga siswa mampu mengaktualisasikan kamampuan didalam luar kelas".

Rochman Natawijaya (dalam jurnal Hera, 2017, hlm. 42), mendifinisikan "Aktivitas belajar merupakan segala keinginan yang dilakukan dalam proses interaksi antara guru dan siswa dalam rangka mencapai tujuan belajar".

Aktivitas guru pada siklus I yang terdiri dari 2 pertemuan pada 
subtema wujud benda dan cirinya menunjukkan bahwa guru belum mencapai indikator yang sudah ditentukan yaitu $80 \%$. Sedangkan pada siklus II yang terdiri dari pertemuan 3 dan 4, aktivias guru sudah. Selanjutnya aktivitas guru semakin meningkat di siklus III pada pertemuan 5 dan 6 . Pada siklus III ini aktivitas guru sudah mencapai indikator ketercapaian termasuk dalam kategori sangat baik.

Rekapitulasi aktivitas guru dan siswa dapat dilihat pada diagram dibawah ini:

Diagram 4.17

Rekapitulasi Aktivitas Guru

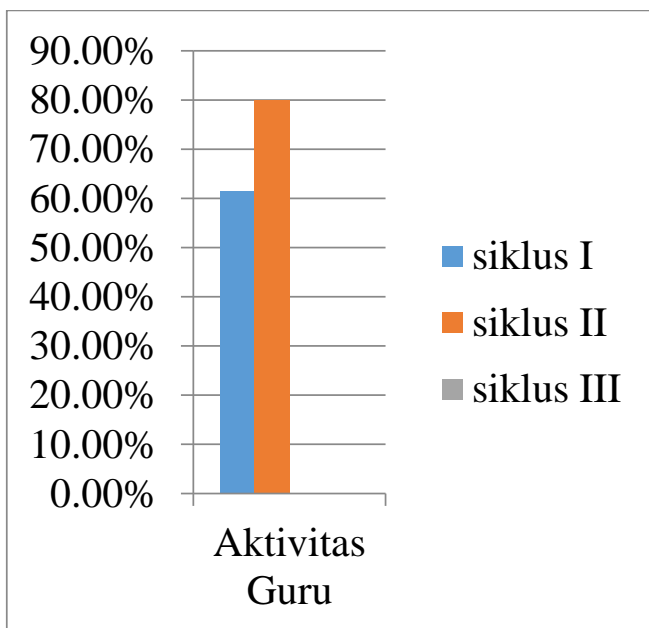

Berdasarkan diagram diatas pada siklus I aktivitas guru yang tuntas jika di presentasekan memperoleh $61,51 \%$, di siklus II mengalami sedikit peningkatan yaitu $80,08 \%$ dan pada siklus III mengalami peningkatan sebanyak $88,44 \%$ yang telah mencapai indikator ketercapaian yaitu $80 \%$.

Diagram 4.18

Rekapitulasi Aktivitas

Siswa

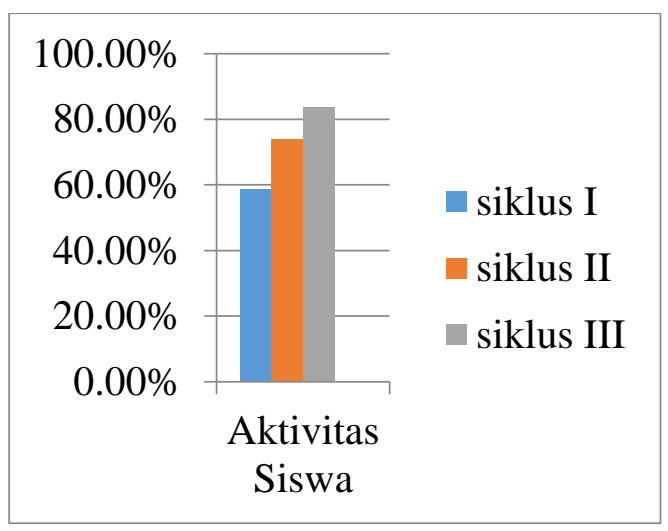

Berdasarkan diagram diatas pada siklus I aktivitas siswa yang tuntas jika di presentasekan sekitar $58,57 \%$, di siklus II mengalami peningkatan yang baik yaitu $80 \%$, dan pada siklus III mengalami peningkatan sebanyak $90 \%$ yang telah mencapai indikator ketercapaian yang telah di tentukan yaitu $80 \%$

\section{Rekapitulasi Hasil Belajar siswa}


Pada pembelajaran siklus I sebagaian peserta didik masih kurang aktif hal ini dikarenakan peserta didik belum bisa menyesuaikan pembelajaran dengan peneliti yang merupakan Guru baru bagi mereka dan kurang bisa menyesuaikan pembelajran dengan model Discovery Learning dimana pembelajaran yang sebelumnya mereka hanya mendengarkan ceramah gurunya dan mengerjakan tugas tanpa mengetahui sampai mana tingkat pemahaman peserta didik yang dikuasai mereka . pada pembelajaran ini peserta didik di ajak bermain tebak - tebakan dimana peserta didik harus menjawab pertanyaan dari pendidik sebagai langkah awal dalam menerapkan model pembelajaran Discovery . pada awal pembelajaran peserta didik masih ada yang malu - malu namun dalam waktu yang singkat peserta didik terlihat aktif dalam menjawab sehingga ketagihan untuk jawab pertanyaan . hal ini berakibat penelitian terus meningkat setiap siklusnya di banding awal penelitian. Beberapa pengertian ahli yang terkait dengan hasil belajar adalah :

Purwanto (2014, hlm.45) mengemukakan "Hasil belajar dapat dijelaskan dengan memahami dua kata yang membentuknya yaitu "hasil" dan "belajar". Pengertian hasil menunjukan pada suatu perolehan akibat dilakukan suatu aktivitas atau proses yang mengakibatkan berubahnya input secara fungsional".

Hasil adalah perolehan yang didapatkan karena adanya kegiatan mengubah bahan menjadi barang jadi. Hal yang sama berlaku untuk memberikan batasan bagi istilah hasil panen, hasil penjualan, hasil pembangunan, termasuk hasil belajar. Dalam siklus input proses hasil, hasil dapat dengan jelas dibedakan dengan input akibat perubahan oleh proses. Begitu pula dalam kegiatan belajar mengajar, setelah mengalami belajar siswa berubah perilakunya dibanding sebelumnya.

Rekapitulasi hasil belajar peserta didik dapat di lihat melalui diagram di bawah ini : 
Diagram 4.19

Rekapitulasi Hasil Belajar siswa

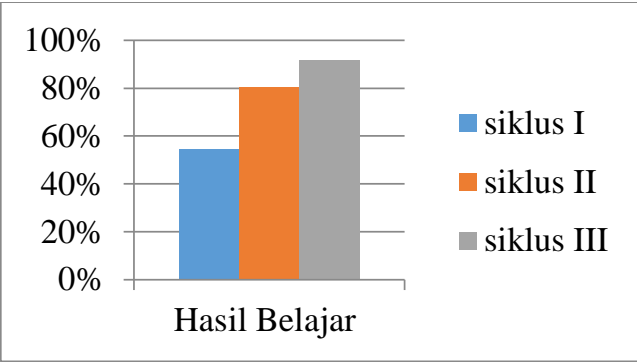

Berdasarkan diagram diatas

pada siklus I hasil belajar peserta didik yang tuntas jika di presentase kan sekitar 54,61\%, di siklus II mengalami banyak peningkatan yaitu $80,38 \%$ dan pada siklus III mengalami peningkatanangat baik sebanyak $91,78 \%$ yang telah mencapai indikator ketercapaian yaitu $80 \%$

\section{Kesimpulan}

Berdasarkan hasil penelitian tindakan kelas yang dilaksanakan di SDN Rancasawo 01 untuk penggunaan model pembelajaran Discovery Learning untuk meningkatkan aktivitas dan hasil belajar siswa kelas $\mathrm{V}$ pada Tema Benda-benda di Lingkungan Sekitar Subtema Wujud Benda dan Cirinya pada pra pembelajaran jumlah siswa yang tuntas dalam mengikuti pembelajaran sangat rendah dan mencapai hasil yang sesuai dengan tujuan.

Berdasarkan hasil penelitian dan pembahasan mulai siklus I sampai siklus ke III dapat diuraikan sebagi berikut :

1. Pada kegiatan perencanaan pelaksanaan pembelajaran pada tema Benda-benda di Lingkungan Sekitar dengan menggunakan model pembelajaran discovery learning untuk meningkatkan aktivitas dan hasil belajar siswa kelas $\mathrm{V}$ SDN Komplek RancasawoMargasari pada siklus I dengan persentase $66,66 \%$, selanjutnya pada siklus II dengan presentase nilai $83,33 \%$, sedangkan pada siklus III dengan persentase $90 \% \%$ maka peningkatan rencana pelaksanaan pembelajaran yaitu sebesar $79,99 \%$.

2. Pada pelaksanaan pembelajaran dengan menggunakan model pembelajaran Discovery Learning dapat meningkatkan ativitas dan hasil belajar siswa kelas V SDN komplek 
Rancasawo-margasari pada

Tema Benda-benda di

Lingkungan Sekitar pada siklus

I dengan persentase sebesar

$68,66 \%$, selanjutnya pada siklus II dengan persentase sebesar 80,66\%dan pada siklus III dengan persentase sebesar 90\%, maka peningkatan pelaksanaan pembelajaran sebesar nilai rata rata $79,77 \%$.

3. Pada aktivitas guru dengan menggunakan model pembelajaran Discovery Learning dapat meningkatkan ativitas dan hasil belajar siswa kelas V SDN komplek Rancasawo-margasari pada Tema Benda-benda di Lingkungan Sekitar pada siklus I dengan persentase sebesar $61,51 \%$, selanjutnya pada siklus II dengan persentase sebesar $80,08 \%$, dan pada siklus III dengan persentase sebesar 88,44\%, maka peningkatan pelaksanaan pembelajaran sebesar nilai rata rata $76,67 \%$

4. Pada aktivitas siswa dengan menggunakan model pembelajaran

Discovery Learning dapat meningkatkan ativitas dan hasil belajar siswa kelas V SDN komplek Rancasawo-margasari pada Tema Benda-benda di Lingkungan Sekitar pada siklus I dengan persentase sebesar $58,75 \%$, selanjutnya pada siklus II dengan persentase sebesar $80 \%$, dan pada siklus III dengan persentase sebesar $90 \%$ maka peningkatan pelaksanaan pembelajaran sebesar nilai rata rata $76,25 \%$

5. Hasil belajar siswa dengan menggunakan penerapan model pembelajaran discovery leraning pada Tema 1 Bendabenda di Lingkungan Sekitar nilai siklus I dengan persentase ketuntasan sebesar $54,61 \%$ termasuk ke dalam kategori "Sangat Kurang", sedangkan pada siklus II dengan persentase ketuntasan sebesar $80,38 \%$ termasuk dalam kategori "Baik", rata-rata nilai pada siklus III dengan persentase ketuntasan sebesar $91,78 \%$ termasuk dalam kategori "Sangat Baik". 
Bedasarkan persentase

tersebut maka peningkatan ketuntasan hasil belajar siswa pada kelas V SDN Rancasawo 01 adalah sebesar 75,57\%. Dengan demikian dapat disimpulkan bahwa penggunaan model pembelajaran discovery learning dapa meningkatkan hasil belajar siswa Pada Tema Benda-Benda di Lingkungan Sekitar.

Berdasarkan hasil tersebut maka hasil belajar siswa kelas $\mathrm{V}$ SDN Rancasawo 01 pada tema benda-benda di lingkungan sekitar dengan menggunakan model discovery learning memperoleh nilai di atas 70 atau telah mencapai KKM. Dengan demikian dapat disimpulkan bahwa penggunaan model discovery learning dapat meningkatkan hasil belajar siswa sudah mencapai Kriteria Ketuntasa Minimal (KKM) 70 sebanyak 90\% sudah tercapai.

6. Dalam

pelaksanaan

pembelajaran peneliti menemi hambatan dalam penerapan model pembelajaran hal ini sejalan dengan hipotesis peneliti yang berbunyi " Jika guru melaksanakan proses pembelajaran di kelas $\mathrm{V}$ SDN Rancasawo 01 pada subtema benda-benda di lingkungan sekitar dengan menggunakan model discovery learning maka akan mengalami hambatan, baik eksternal maupun internal" adapun beberapa hambatan yang di temui adalah

a. Kondisi ruang kelas yang kurang kondusif

b. Sarana dan prasarana sekolah yang belum memadai

c. Kurangnya aktivitas siswa saat pembelajaran di kelas

7. Dengan di temukannya hambatan pada pelaksanaan penelitian maka peneliti berusaha untuk mencari upaya untuk mengatasi hambatan tersebut agar aktivitas dan hasil belajar siswa dapat meningkat dengan menggunakan model discovery learning, hal ini sejalan dengan hipotesis yang berbunyi " Jika guru berupaya untuk mengatasi hambatan dalam menerapkan model discovery learning pada 
subtema wujud benda dan cirinya maka hasil belajar dan kerjasama siswa mampu meningkat", jadi upaya yang di lakukan adalah :

a. Guru dan siswa mengadakan penataan kelas agar terlihat lebih teratur ,rapih, nyaman, dan mendukung untuk belajar.

b. Guru harus memiliki keterampilan dan kreatifitas dalam menentukan media dan bahan ajar dalam pembelajaran

c. Guru memberikan stimulus pada siswa untuk bergerak aktif di dalam kelas khususnya dalampembelajaran.

Hasil penelitian tindakan kelas dengan menggunakan model pembelajaran Discovery Laerning pada Tema Benda-benda di Lingkungan Sekitar dapat meningkatkan aktivitas dan hasil belajar siswa pada kelas $\mathrm{V}$ SDN Rancasawo 01, di lihat dari cara siswa berinteraksi dalam pembelajaran baik itu dengan guru maupun dengan teman sebayanya, dapat memecahkan masalah dalam pembelajaran yang diberikan oleh guru, dan sangat termotivasi untuk mengikuti arahan guru.

Maka dapat ditarik
kesimpulan bahwa model
pembelajaran discovery learning
dapat meningkatkan aktivitas dan
hasil belajar siswa, hal ini terbukti
dengan adanya peningkatan pada
tiap siklus. Serta cocok digunakan
oleh pendidik untuk proses pembelajaran yang selanjutnya.

Berdasarkan hasil pembahasan pada penelitian ini dapat disimpulkan bahwa penggunaan model pembelajaran discovery learning mulai dari siklus pertama, sampai siklus terakhir memperlihatkan adanya peningkatan antusias dan aktivitas siswa dalam belajar. Hal ini berkaitan erat dengan model discovery learning karena model ini mampu memotivasi siswa untuk bisa menggali suatu topik pemasalahan dan mampu meningkatkan antusiasnisme, aktivitas siswadalam pembelajaran di dalam kelas maka hal ini terbukti berhasil dalam kemajuan inovasi pendidikan terutama hasil belajar.

\section{DAFTAR PUSTAKA}


2003.Undang-Undang

Indonesia Nomor

2003 Tentang

Republik

20 Tahun

Sistem

Pendidikan Nasional. Jakarta:

Departemen Pendidikan

Nasional Republik Indonesia.

Arikunto, S. 2012. Penelitian Tindakan Kelas. Jakarta: Bumi Aksara

Eva Royani Mushtofa. 2017. Penggunaan Model Contextual Tearching And Learning Untuk Meningkatkan Aktivitas Dan Hasil Belajar Siswa Dalam Pembelajaran IPA Pokok Bahasan Mengenal Struktur Tumbuhan Dikelas IV SDN Durma Kecamatan Andir Kota Bandung.

(Online). Http://repository.unpas.ac.id/14 028/ (diakses 13 juni 2017)

FKIP UNPAS. 2017. Panduan Penulisan Karya Tulis Ilmiah (KTI). Bandung: Perpustakaan Nasional

Heriawan, Adang. 2012. Metodologi Pembelajaran Kajian Teoritis Praktis.

Serang-Banten: LP3G (Lembaga Pembinaan dan Pengembangan Profesi Guru).

Hendri. 2016. Penerapam Model Discovery Learning untuk Meningktkan Hasil

Belajar Siswa pada Tema Indahnya Kebersamaan Subtema Keberagaman Budaya Bangsaku. UNPAS. Tidak Diterbitkan.

Hera Heryani Rosadah. 2017. Upaya Meningkatkan Aktivitas Dan Hasil BelajarSiswa Pada Mata Pelajaran IPS Kelas IV Pada Materi Keragaman Suku
Bangsa Dan Budaya Melalui Model Cooperative Learning Tipe Jigsaw. (online). http://repository.unpas.ac.id/15 386/ (diakses pada 13 Juni 2017)

lit Sri Latifah. (2016). Penggunaan Model Discovery Learning Untuk

Meningkatkan Sikap Prcaya Diri Dan Hasil Belajar Siswa. (Online).

http://repository.unpas.ac.id/68 63/ (diakses 20 Mei 2017)

llahi, Mohammad Takdir. 2012. Pembelajaran Discovery Strategi Dan Mental Vocational Skill. Yogyakarta: Diva Press.

Iskandar. 2015. Penelitian Tindakan Kelas dan Publikasinya. Cilacap: Ihya Media

Jufri, Wahab. 2017. Belajar Dan Pembelajaran Sains. Bandung: Pustaka Reka Cipta

Kiki Nurjaman. (2016). Penggunaan Model Problem Base Learning untuk

Meningkatkan Aktivitas dan Prestasi Belajar Siswa dalam Mata Pelajaran IPS Materi Perkembangan Teknologi Produksi Komunikasi dan

Transportasi.(Online). http://repository.unpas.ac.id/12 863/ (diakses 10 juni 2017)

Kunandar. 2015. Penilaian Autentik (Penilaian Hasil Penilaian Peserta Didik

Berdasarkan Kurikulum 2013). Jakarta: PT Rajagrafindo Persada. 
Lisma Damayani. (2017). Model Discovery Learning untuk Meningkatkan Hasil

Belajar Siswa pada Subtema Hidup Rukun dengan Teman Bermain.

(Online).http://repository.unpas.ac.i d/15362/ (diakses 29 juni 2017)

Mulyasa. 2016. Implementasi Kurikulum 2013. Bandung: PT Remaja Rosda

Karya.

Mia Anggraeni. (2016). Penggunaan Model Discovery Learning untuk

Meningkatkan Aktivitas dan Hasil Belajar dalam Pembelajaran IPA

Materi Fungsi Organ Tubuh Manusia dan Hewan. (Online).

http://repository.unpas.ac.id/12702/ (diakses 29 juni 2017)

Mila Sari. 2017. Pengaruh Penerapan Metode Pembelajaran Drill And Practice

Terhadap Aktivitas Belajar Siswa (Studi Kasus Mata Pelajaran Akuntansi

Pokok Bahasan Jurnal Umum Kelas X SMAN 5 Kota Sukabumi Tahun

Ajaran 2015-2016). (Online). http://repository.unpas.ac.id/14 778/ (diakses

10 juni 2017)

Purwanto, 2014. Evaluasi Hasil Belajar. Yogyakarta: Pustaka Belajar.
Rina Agustina. (2016). Penggunaan Model Discovery Learning untuk

Meningkatkan Hasil Belajar Siswa pada Subtema Manfaat Makanan Sehat

dan Bergizi. (Online). http://repository.unpas.ac.id/11 291/ (diakses 15 mei 2017)

Rizal Wildan Fauzi. (2016). Penggunaan Model Discovery Learning untuk

Menumbuhkan Sikap Cinta Lingkungan dan Kreatif Serta Meningkatkan

Hasil Belajar pada Tema Berbagai Pekerjaan. (Online).

http://repository.unpas.ac.id/13145/ (diakses 29 juni 2017)

Ripa Siti Fitriani.(2016). Penggunaan Model Discovery Learning untuk

Menumbuhkan kemampuan berfikir kritis dan hasil belajar siswa pada

Mata Pelajaran IPA Materi Fungsi Alat Indera Manusia dan

Pemeliharaannya.(Online). http://repository.unpas.ac.id/12 811/ (diakses

29 juni 2017).

Rusman. 2012. Model-model pembelajaran. Jakarta: PT Rajagrafindo Persada

Siti Honijah. (2016). Penggunaan Model untuk Meningkatkan Aktivitas dan Hasil

Belajar Siswa pada Pelajaran IPA Materi Fungsi Organ Tubuh Manusia dan Hewan. (online). 
http://repository.unpas.ac.id/12 705/ (diakses 10 juli 2017)

Sudjana, Nana. 2016. Penilaian Hasil Proses Belajar Mengajar. Bandung: PT

Remaja Rosdakarya

Suprihatiningrum, Jamil. 2016.

Strategi Pemblejaran Teori dan Aplikasi.

Yogyakarta: Ar-Ruzz Media.

Shoimin, Aris. 2014. 68 Model Pembelajaran Inovatif dalam Kurikulum 2013.

Yogyakarta: Ar-Ruzz Media.

Sanie lazuwardiyati. (2016). Penerapan Model Discovery Learning Untuk

Meningkatkan Motivasi Dan Hasil Belajar Siswa Dalam Pelajaran IPS
Pada Materi Perkembangan Teknologi. (Online).

http://repository.unpas.ac.id/10029/ (diakses 15 Mei 2017)

Sugiyono. 2017. Metode Peneitian Kuamtitatif, Kualitatif dan R\&D. Bandung: Alfabeta Bandung

Tim FKIP UNPAS. 2017. Panduan Penulisan Karya Tulis IImiah (KTI). Bandung: FKIP UNPAS

Thobroni, 2015. Belajar Dan Pembelajaran Teori Dan Praktik. Yogyakarta: Ar Ruzz Media

Trianto. 2015. Mendesain Model Pembelajaran Inovatif, Progresif, dan Kontekstual. Jakarta: PT Kharisma Pratama Utama. 